Hal : $14-20$

\title{
ANALISIS YANG MEMPENGARUHI KEDISIPLINAN SISWA TERHADAP MINAT BELAJAR SISWA DI KELAS X SMA NEGERI 1 MERBAU KECAMATAN MERBAU KABUPATEN LABUHANBATU UTARA PADA TAHUN 2018.
}

\author{
Susi Nurlianti ${ }^{1}$ ), Rohana ${ }^{2}$ ) \\ 1) Mahasiswa Prodi PPKn Sekolah Tinggi Keguruan dan IImu Pendidikan Labuhan Batu \\ 2) Prodi PPKn Sekolah Tinggi Keguruan dan IImu Pendidikan Labuhan Batu \\ Email: Susinurlianti99@gmail.com \\ hanasyarif85@gmail.com
}

Diterima Oktober 2018 dan Disetujui Desember 2018

\begin{abstract}
ABSTRAK
Penelitian ini bertujuan untuk mengetahui analisis yang mempengaruhi kedisiplinan Terhadap minat belajar siswa, dan untuk mengetahui faktor kedisiplinan dan minat belajar yang dapat dianalisis di SMA Negeri 1 Merbau Kecamatan Merbau Kabupaten Labuhanbatu Utara pada Tahun Pembelajaran 2017/2018. Metode penelitian ini menggunakan deskriftif kualitatif. Instrumen yang dipakai dalam penelitian ini menggunakan angket yang ditujukan kepada siswa dan wawancara dengan Guru mata pelajaran Pendidikan Kewarganegaraan. Sampel dalam penelitian ini masingmasing berjumlah 32 siswa yaitu pada kelas X-MIPA2 dan X-IIS. Berdasarkan hasil penelitian yang sudah dilakukan dapat dilihat perbandingan diagram pada kedua kelas tersebut terlihat bahwa pada kelas X-MIPA2 responden terbanyak berjumlah 12 siswa yang memilih setuju dan tidak setuju presentasenya (37,5\%) maka dikategorikan Ragu-ragu, sedangkan pada kelas X-IIS1 siswa terbanyak yang memilih Setuju berjumlah 13 siswa dengan presentase $(40,62 \%)$ maka disimpulkan sikap disiplin siswa yang lebih unggul jumlah presentasenya yaitu pada kelas X-IIS1 dibanding kelas X-MIPA1 disebabkan karena kedisiplinan lebih diutamakan dikelas tersebut yang merupakan suatu ciri khusus bagi kelas X-IIS1 sehingga menjadikan kelas yang mempunyai kedisiplinan yang cukup tinggi. Perbandingan diagram pada kedua kelas terlihat bahwa kelas X-MIPA2 banyak siswa yang memilih kategori Senang berjumlah 16 presentase (50\%) sedangkan pada kelas X-IIS1 banyak siswa yang memilih Kategori Senang berjumlah 14 presentase $(43,75 \%)$ maka disimpulkan minat belajar siswa berpengaruh dalam belajar yang lebih unggul jumlah presentasenya yaitu pada kelas X-MIPA2 disebabkan karena siswa aktif dan semangat belajarnya cukup tinggi sehingga proses belajarnya berdampak baik. Dengan penjabaran diatas dapat disimpulkan bahwa kedisiplinan dan minat belajar siswa berpengaruh dalam aktivitas belajar siswa, Maka dalam hal ini perlu ada peraturan yang tegas dari pihak sekolah untuk meningkatkan perilaku disiplin siswa dan minat belajar siswa tersebut seimbang sebagaimana mestinya, agar terciptanya belajar yang aktif serta kreatif.
\end{abstract}

Kata Kunci : Kedisiplinan, Minat Belajar Siswi

\section{PENDAHULUAN}

Fenomena yang ditemukan di SMA

Negeri 1 Merbau Kecamatan Merbau Kabupaten Labuhanbatu Utara diketahui bahwa banyak Siswa yang melanggar disiplin sekolah yang telah ditetapkan.
Berdasarkan Observasi awal yang dilakukan peneliti selama Praktek lapangan kependidikan peneliti menemukan ada beberapa pelanggaran tata tertib yang yang dilakukan oleh Siswa seperti: 1). Model rambut yang tidak sesuai dengan model rambut anak sekolah bagi siswa laki - laki 
(tidak boleh melebihi kera baju kemeja), 2). Keluar dari kelas apabila ada guru pelajaran yang tidak datang atau terlambat masuk, 3). Keluar pada saat jam pergantian pelajaran, 4). Permisi melebihi satu orang perkelas, 5). Datang terlambat (tidak tepat waktu), 6). Nongkrong di kantin pada saat jam belajar berlangsung, 7). Ribut di kelas pada saat guru belum datang, 8). Berpakaian tidak rapi layaknya tidak sesuai dengan pakaian anak sekolah, 9) main handphone pada saat jam belajar berlangsung, 10). Atribut tidak lengkap, dan lain sebagainya. Kedisiplinan adalah sikap seseorang yang menunjukkan ketaatan atau kepatuhan terhadap peraturan atau tata tertib yang telah ada dan dilakukan dengan senang hati dan kesadaran diri. Disiplin adalah tindakan yang senantiasa berdasar pada tata tertib yang sudah digariskan. Untuk mencapai suatu prestasi yang baik diperlukan kedisiplin yang tinggi. Ada yang mengatakan bahwa ketidak disiplinan mengakibatkan tertundanya pencapaian prestasi. Hal ini dapat dimaklumi, sebab tidak adanya kedisiplinan tentang waktu, upaya memenuhi program, dan adanya kecenderungan berbuat sekehendak hati. (Iskandar, 2010:88)

Menurut Slameto (2010:180) minat adalah suatu rasa lebih suka dan rasa keterikatan pada suatu hal atau aktivitas, tanpa ada yang menyuruh. Minat pada dasarnya adalah penerimaan akan suatu hubungan antara diri sendiri dengan sesuatu diluar diri. Semakin kuat atau dekat hubungan tersebut, semakin besar minat.

\section{METODE PENELITIAN \\ Tempat dan Waktu Penelitian}

Penelitian ini dilaksanakan di SMA

Negeri 1 Merbau Kecamatan Merbau Kabupaten Labuhanbatu Utara. Adapun waktu penelitian ini akan dilakukan pada bulan Mei sampai bulan Juni Tahun 2018.

\section{Jenis Penelitian}

Jenis penelitian yang dipakai oleh peneliti adalah fenomenologi yang mempelajari masalah - masalah yang ada serta tata tertib yang berlaku. Penelitian ini ini untuk mendeskripsikan apa-apa yang saat ini berlaku. Didalamnya terdapat upaya mendeskripsikan, mencatat, analisis, dan melihat kondisi yang sekarang ini terjadi atau ada. Penelitian ini bertujuan untuk memperoleh informasi - informasi mengenai keadaan - keadaan yang ada.

Prosedur Penelitian

Dalam Penelitian Kualitatif ini peneliti beberapa tahapan, sebagai berikut:

1)Tahap Persiapan

a) Membuat kisi - kisi angket / kuesioner dengan beberapa variabel dan subvariabel yang akan diungkap dengan batasan sesuai dengan judul penelitian.

b) Membuat pertanyaan sesuai dengan dengan kisi - kisi yang telah dibuat

2)Tahap Pelaksanaan

Pelaksanaan Pengambilan data dilakukan pada beberapa siswa di SMA Negeri Merbau Kecamatan Merbau Kabupaten Labuhanbatu Utara.

3)Tahap Mengumpulkan Data

Apabila peneliti sudah menentukan data apa yang akan dikumpulkan, dari mana data tersebut dapat diperoleh yaitu dengan wawancara dengan guru mata pelajaran Pendidikan Kewarganegaraan (PKn) dan Penyebaran angket pada kelas X-MIPA2 yang berjumlah 32 siswa dan kelas X-IIS1 yang berjumlah 32 siswa. maka peneliti sendiri maupun orang lain yang akan membantu, dalam penelitian tersebut.

4)Tahap Analisis Data

Tugas menganalisis data tidak seberat mengumpulkan data, baik tenanga maupun pertanggungjawaban. Akan tetapi menganalisis data membutuhkan ketekunan dan pengertian terhadap jenis data akan menuntut teknis analisis data.

5) Tahap Menarik Kesimpulan

Langkah terakhir dari kegiatan penelitian. Pekerjaan peneliti telah selesai, dan peneliti tinggal mengambil kesimpulan dari hasil pengolahan data.

\section{Instrumen Penelitian Wawancara}

Jenis wawancara dalam penelitian kualitatif ini peneliti memakai wawancara tak terstruktur (unstructured interview). Wawancara tak terstruktur (unstructured interview) adalah wawancara yang bebas dimana peneliti tidak menggunakan pedoman wawancara yang telah tersusun secara 
Hal : $14-20$

sistematis dan lengkap untuk mengumpulkan datanya.

\section{Angket}

Angket adalah teknik pengumpulan data yang dilakukan dengan cara memberi seperangkat pertanyaan atau pernyataan HASIL DAN PEMBAHASAN tertulis kepada responden untuk dijawabnya. (Sugiyono, 2016:142)

Angket ini digunakan bila responden jumlah besar dapat membaca dengan baik, dan dapat mengungkapkan hal-hal yang sifatnya rahasia. maka jawaban itu dapat berupa rumus Presentase responden.

Tabel. 1. Kesimpulan Angket Kedisiplinan pada Kelas X-MIPA2 dan X-IIS1

\begin{tabular}{llcc}
\hline No & Kategori Jawaban & Jumlah Responden & Presentase \\
\hline 1 & Sangat Senang & 9 & $14,0625 \%$ \\
2 & Senang & 16 & $25 \%$ \\
3 & Ragu-ragu & 15 & $23,4375 \%$ \\
4 & Sangat Ragu-ragu & 12 & $18,75 \%$ \\
5 & Sangat Tidak Senang & 12 & $18,75 \%$ \\
& Jumlah & $\mathbf{6 4}$ & $\mathbf{1 0 0 \%}$ \\
\hline
\end{tabular}

Secara keseluruhan siswa menjawab paling banyak pernyataan Sangat Setuju dan Setuju terdapat 25 jumlah responden maka presentasenya $39,06 \%$ siswa, maka dikategorikan Setuju, hal ini berarti bahwa siswa hanya sebagian saja yang melanggar peraturan sekolah dan sebagiannya lagi siswa yang menaati peraturan, selain itu siswa juga tidak selalu sering melanggar aturan sekolah dan juga selalu melanggar aturan tersebut dikarenakan faktor keadaan siswa, kondisi siswa, ataupun faktor teman sepermainan, dan Faktor keluarga, Faktor lingkungan, dan lain sebagainya. Hal ini membuktikan agar pihak sekolah lebih meningkatkan lagi dengan memberikan arahan dan bimbingan pada siswa serta sanksi yang tegas supaya siswa tidak melanggar peraturan yang telah ditetapkan di sekolah agar tujuan menciptakan anak bangsa dapat terlaksana dan tercapai sebagaimana mestinya.

Tabel.2. Kesimpulan Angket Minat Belajar Siswa pada Kelas X-MIPA2 dan X-IIS1

\begin{tabular}{llcc}
\hline No & Kategori Jawaban & Jumlah Responden & Presentase \\
\hline 1 & Sangat Senang & 14 & $21,875 \%$ \\
2 & Senang & 15 & $23,4375 \%$ \\
3 & Ragu-ragu & 20 & $31,25 \%$ \\
4 & Sangat Ragu-ragu & 12 & $18,75 \%$ \\
5 & Sangat Tidak Senang & 3 & $4,6875 \%$ \\
& Jumlah & $\mathbf{6 4}$ & $\mathbf{1 0 0} \%$ \\
\hline
\end{tabular}

Sangat Senang dan Senang terdapat jumlah responden 29 siswa presentasenya $45,31 \%$ siswa maka dikategorikan Senang , hal ini berarti bahwa siswa hanya sebagian saja yang tidak berminat dalam belajar dan sebagiannya lagi siswa yang minat belajarnya sangat tinggi, selain itu siswa juga tidak selalu sering melanggar paturan didalam kelas dan juga selalu melanggar aturan tersebut dikarenakan bosan, malas, kurangnya daya tarik pendidik untuk menumbuhkembangkan minat belajar siswa, dan kurangnya motivasi siswa ataupun semangat siswa yang kurang dan sebab lainnya. Hal ini membuktikan agar para guru lebih mengoptimalkan dan profesional lagi dalam menumbuhkembangkan semangat belajar siswa agar lebih meningkat dan berhasil sesuai yang dicapai.

\section{Pembahasan Hasil Penelitian}

Berdasarkan penelitian yang telah dilaksanakan peneliti melalui angket dengan siswa maka setelah dilakukan penelitian dapat diperoleh data angket secara menyeluruh dari kedua kelas yang di pilih oleh peneliti yaitu kelas (X-MIPA2 dan X-IIS1) masing - masing berjumlah 32 maka jumlah 
Hal : $14-20$

siswa keseluruhannya dengan disebarkannya 64 siswa dengan menyebar angket Kedisiplinan dan Minat belajar siswa di masing-masing kelas. Hal ini menujukkan dimana rumusan masalah tersebut yaitu "Bagaimanakah Analisis yang mempengaruhi Kedisiplinan Terhadap Minat Belajar Siswa di angket

berjumlah

SMA Negeri 1 Merbau Kecamatan Merbau Kabupaten Labuhanbatu utara Pada Tahun Pembelajaran 2017/2018" maka setelah dilakukan penelitian dapat diperoleh data angket secara keseluruhannya sebagai berikut:

Tabel.3. Kesimpulan Angket Kedisiplinan pada kelas X-MIPA2

\begin{tabular}{llcc}
\hline No & Kategori Jawaban & Jumlah Responden & Presentase \\
\hline 1 & Sangat Setuju & 5 & $15,625 \%$ \\
2 & Setuju & 7 & $21,875 \%$ \\
3 & Ragu-ragu & 8 & $25 \%$ \\
4 & Tidak Setuju & 6 & $18,75 \%$ \\
5 & Sangat Tidak Setuju & 6 & $18,75 \%$ \\
& Jumlah & $\mathbf{3 2}$ & $\mathbf{1 0 0 \%}$ \\
\hline
\end{tabular}

Tabel.4. Kesimpulan Angket Kedisiplinan Pada Kelas X-MIPA2 dan X-IIS1

\begin{tabular}{llcc}
\hline No & Kategori Jawaban & Jumlah Responden & Presentase \\
\hline 1 & Sangat Setuju & 4 & $12,5 \%$ \\
2 & Setuju & 9 & $28,125 \%$ \\
3 & Ragu-ragu & 7 & $21,875 \%$ \\
4 & Tidak Setuju & 6 & $18,75 \%$ \\
5 & Sangat Tidak Setuju & 6 & $18,75 \%$ \\
& Jumlah & $\mathbf{3 2}$ & $\mathbf{1 0 0 \%}$ \\
\hline
\end{tabular}

Maka dilihat perbandingan pada pernyataan angket kedisiplinan siswa pada kelas X-MIPA2 jumlah siswa yang memilih Sangat Setuju (15,625\%), jumlah siswa yang memilih Setuju (21,875\%), siswa yang memilih Ragu-ragu (25\%), siswa yang memilih Tidak Setuju (18,75\%), dan siswa yang memilih Sangat Tidak Setuju (18,75\%). Sedangkan pada kelas X-IIS1 jumlah siswa memilih Sangat Setuju (12,5\%), jumlah siswa yang memilih Setuju $(28,125 \%)$, siswa yang memilih Ragu-ragu (21,875\%), siswa yang memilih Tidak Setuju (18,75\%), dan siswa yang memilih Sangat Tidak Setuju (18,75\%). Dilihat perbandingan diagram pada kedua kelas tersebut terlihat bahwa pada kelas $X$ MIPA2 responden terbanyak berjumlah 12 siswa yang memilih setuju dan tidak setuju presentasenya $(37,5 \%)$ maka dapat dikategorikan Ragu-ragu disimpulkan kedisiplinan siswa berpengaruh pada kelas tersebut dikarenakan siswa yang kurang mematuhi peraturan yang ada di sekolah tersebut disebabkan kebiasaan siswa, kurang tegas nya peraturan yang ditegakkan di sekolah tersebut dan faktor lainnya, sedangkan dilihat dari kelas X-IIS1 siswa terbanyak yang memilih Setuju berjumlah 13 siswa maka presentasenya $(40,62 \%)$ dan siswa yang memilih Tidak Setuju berjumlah 12 dengan presentase (37,5\%) maka disimpulkan sikap disiplin siswa yang lebih unggul jumlah presentasenya yaitu pada kelas X-IIS1 dikarenakan Setuju dibanding kelas X-MIPA1 disebabkan karena kedisiplinan lebih diutamakan dikelas tersebut yang merupakan suatu ciri khusus bagi kelas X-IIS1 sehingga menjadikan kelas yang mempunyai kedisiplinan yang cukup tinggi. 
Hal : $14-20$

Tabel.5. Kesimpulan Angket Minat Belajar Siswa Pada Kelas X-MIPA2

\begin{tabular}{llcc}
\hline No & Kategori Jawaban & Jumlah Responden & Presentase \\
\hline 1 & Sangat Senang & 8 & $25 \%$ \\
2 & Senang & 8 & $25 \%$ \\
3 & Ragu-ragu & 9 & $28,125 \%$ \\
4 & Sangat Ragu-ragu & 6 & $18,75 \%$ \\
5 & Sangat Tidak Senang & 1 & $3,125 \%$ \\
& Jumlah & $\mathbf{6 4}$ & $\mathbf{1 0 0} \%$ \\
\hline
\end{tabular}

Tabel.6. Kesimpulan Angket Minat Belajar Siswa Pada Kelas X-MIPA2

\begin{tabular}{llcc}
\hline No & Kategori Jawaban & Jumlah Responden & Presentase \\
\hline 1 & Sangat Senang & 6 & $18,75 \%$ \\
2 & Senang & 7 & $21,875 \%$ \\
3 & Ragu-ragu & 11 & $28,125 \%$ \\
4 & Sangat Ragu-ragu & 6 & $18,75 \%$ \\
5 & Sangat Tidak Senang & 2 & $6,25 \%$ \\
& Jumlah & $\mathbf{6 4}$ & $\mathbf{1 0 0} \%$ \\
\hline
\end{tabular}

Maka dilihat perbandingan pada pernyataan angket minat belajar siswa pada kelas X-MIPA2 jumlah siswa yang memilih Sangat Senang (25\%), jumlah siswa yang memilih Senang (25\%), siswa yang memilih Ragu-ragu (28,125\%), siswa yang memilih Tidak Senang (18,75\%), dan siswa yang memilih Sangat Tidak Senang $(3,125 \%)$. Sedangkan pada kelas X-IIS1 jumlah siswa yang memilih Sangat Senang (18,75\%) jumlah siswa yang memilih Senang $(21,875 \%)$, siswa yang memilih Ragu-ragu $(34,375 \%)$, siswa yang memilih Tidak Senang $(18,75 \%)$, dan siswa yang memilih Sangat Tidak Senang $(6,25 \%)$. Dilihat perbandingan diagram pada kedua kelas tersebut terlihat bahwa kelas X-MIPA2 siswa terbanyak yang memilih kategori Senang berjumlah 16 presentase $(50 \%)$ maka disimpulkan bahwa minat belajar siswa berpengaruh dalam belajar, sedangkan dilihat dari kelas X-IIS1 siswa terbanyak yang memilih Kategori Senang berjumlah 14 presentase $(43,75 \%)$ bahwa minat belajar siswa sangat berpengaruh dalam belajar, maka disimpulkan minat belajar siswa yang lebih unggul jumlah presentasenya yaitu pada kelas X-MIPA2 disebabkan karena siswa aktif dan semangat belajarnya cukup tinggi sehingga proses belajarnya berdampak baik.

Berdasarkan wawancara yang telah dilakukan peneliti oleh Guru mata pelajaran Pendidikan kewarganegaraan (PKn). Maka disini siswa menjadi lebih memahami dan lebih mengutamakan lagi prilaku siswa yang lebih baik lagi. Seperti yang diketahui bahwasannya menumbuh kembangkan sikap siswa kearah yang lebih baik lagi. Selain itu faktor yang membuat kedisiplinan siswa meningkat ketika peraturan sekolah tersebut dengan tegas di terapkan sebagimana mestinya. Dan disini lah siswa merasa bahwa dengan kepedulian para guru ataupun peraturan yang ada di sekolah mereka merasa ditakuti oleh siswa, bahwa dengan begitu siswa dapat mencintai perilaku yang disiplin sebagai mana anak sekolah yang sewajarnya. Maka disini guru peran penting untuk berupaya membangkitkan prilaku disiplin, semangat dan minat belajar siswa untuk memberikan membimbingan, arahan, motivasi, serta membuat daya tarik siswa agar siswa menjadi aktif dan kreatif dalam belajar. Berdasarkan wawancara yang telah dilakukan peneliti oleh Guru pemegang mata pelajaran Pendidikan Kewarganegaraan (PKn) bahwa siswa memiliki semangat yang tinggi serta berprilaku yang baik dan tumbuhnya semangat maka guru yang bersangkutan mengatakan setelah dilaksanakannya penelitian ini maka sekolah SMA Negeri 1 Merbau tersebut menjadi 
Hal : $14-20$

sekolah rujukan dan sekolah yang berkualitas.

Meskipun demikian hasil penelitian yang dilakukan di SMA Negeri 1 Merbau Kabupaten Labuhanbatu Utara di kelas X Tahun Pembelajaran 2017/2018, setelah dilihat perhitungan hasil angket kedisiplinan dan minat belajar siswa terlihat bahwa adanya peningkatan minat belajar siswa lebih tinggi pada kedua kelompok dibandingkan kedisiplinan siswa. Maka yang seharusnya kedisiplinan dan minat belajar tersebut harus seimbang agar terciptanya belajar yang aktif serta kreatif. Maka pihak sekolah perlu ada penegasan lagi untuk ditinjaklanjuti. Adapun Wawancara dalam penelitian ini sangat penting untuk mencari informasi-informasi yang didapat sehingga peneliti dapat mengetahui masalah yang terjadi pada penelitian ini.

\section{Kesimpulan}

1.Berdasarkan hasil pembahasan tentang masalah di dalam penelitian ini peneliti menarik kesimpulan bahwa kedisiplinan sangat mempengaruhi minat belajar siswa karena tanpa adanya disiplin maka kurang nya minat dalam belajar, jadi dari dilaksanakannya penelitian tersebut sudah terbukti kedisiplinan dan minat belajar siswa tidak seimbang sebagaimana mestinya. Maka dalam hal ini perlu ada peningkatan dalam perilaku disiplin siswa agar kedisiplinan dan minat belajar tersebut seimbang dan terciptanya belajar yang aktif serta kreatif. Disini juga Para pengajar guru agar lebih mengoptimalkan dan mengarahkan siswa ke hal-hal yang positif serta memberikan motivasi atau dorongan kepada siswa agar siswa tidak melakukan hal-hal yang dapat merugikan bagi dirinya.

2. Hal ini menunjukkan bahwa dalam penelitian ini faktor yang mempengaruhi kedisiplinan dan minat belajar menunjukkan pada prilaku siswa ataupun kebiasaan siswa yang kurang mematuhi peraturan guru pada saat proses belajar mengajar berlangsung, Malas dan kurangnya minat siswa untuk belajar yang disebabkan waktu jam belajar pada saat les terakhir, Penggunaan metode dan para pengajar guru yang kurang efektif, Peraturan yang sudah di tetapkan kurang tegas tidak menimbulkan efek jera bagi si pelanggar, Maka pihak sekolah perlu ada penegasan lagi untuk ditinjaklanjuti. Adapun Wawancara dalam penelitian ini sangat penting untuk mencari informasi-informasi yang didapat sehingga peneliti dapat mengetahui masalah yang terjadi pada penelitian ini dan penelitian selanjutnya.

\section{Saran}

1.Solusi peneliti dalam menumbuhkan kedisiplinan terhadap minat belajar siswa yaitu dengan cara;

a) Guru BK (Bimbingan Konseling) dalam satu minggu sekali mengontrol siswa ke tiap - tiap kelas dengan merazia handphone bagi siswa yang membawa handphone ke sekolah.

b) Guru Piket mengontrol gerbang pintu masuk sekolah dengan mendatangi Peserta Didik yang ba atang ke sekolah sekaligus memeriksa pakaian serta atribut sekolah.

c) Menambah Fasilitas Belajar Peserta Didik agar terciptanya belajar yang kondusif.

d) Guru piket juga harus mengontrol tempat - tempat rawan seperti kantin, toilet dan tempat - tempat lainnya agar tidak ada lagi siswa yang mangkal di tempat tersebut pada saat jam belajar berlangsung.

e) Para tenaga kerja guru juga harus menumbuhkan semangat belajar siswa dengan menampilkan penampilan yang menawan dan layaknya guru yang kreatif dan profesional agar siswa tidak merasa bosan dalam belajar.

f) Guru BK (Bimbingan Konseling) memberikan sanksi tegas kepada siswa yang melanggar peraturan yang telah di sepakati dengan membawa alat seperti, sapu, kain pel, ember, dan lain sebagainya.

g) Guru juga memberikan perjanjian kepada siswa tentang hal - hal yang mengganggu pelajaran atau kebiasaan Peserta Didik yang di luar batas yang telah di sepakati bersama dengan memberikan sanksi sesuai kelakuan Peserta didik agar menimbulkan efek jera bagi si pelanggar.

h)Guru BK (Bimbingan Konseling) melarang dengan tegas kepada siswa untuk memintak izin meninggalkan sekolah selama jam belajar agar tidak terjadi hal - hal yang tidak di inginkan. 
Hal: $14-20$

i) Guru juga harus konsultasi kepada siswa tentang kesulitan belajar.

j) Guru juga harus menciptakan suasana belajar yang kreatif dan aktif agar siswa tidak merasa bosan dalam proses belajar mengajar di kelas, dan lain sebagainya.

2.Sebelum menanamkan nilai-nilai kedisiplinan pada diri siswa melalui proses belajar mengajar, hendaknya guru memahami hakikat kedisiplinan dan menunjukkan sikap baik di depan siswa pada proses belajar mengajar.

3.Perlu ada pengembangan kearah yang lebih baik dari penggunaan disiplin dalam belajar sehingga penelitian serupa terdapat pengaruh, sehingga penggunaan kedisiplinan dapat diterapkan dalam lingkungan sekolah yang lebih baik.

\section{DAFTAR PUSTAKA}

A.M, Sardiman. 2016. Interaksi dan Motivasi Belajar Mengajar. Penerbit: PT. Raja Grafindo Persada: Jakarta.

Amri, Sopan. 2013. Pengembangan dan Model Pembelajaran dalam Kurikulum $2013 . \quad$ Penerbit: PT.Prestasi Pustakaraya: Jakarta-Indonesia.

Amri, Sopan. 2016. Pengembangan dan Model Pembelajaran dalam Kurikulum 2013. Penerbit: PT.Prestasi Pustakaraya: Jakarta-Indonesia.

Arikunto., Suharsimi. 2014. Prosedur Penelitian Suatu Pendekatan Praktik, Penerbit PT Rineka Cipta: Jakarta.

Dimyanti, dkk. 2013. Belajar dan Pembelajaran. Penerbit: PT Rineka Cipta: Jakarta.

Djamarah, S.B. 2011. Psikologi Belajar. Penerbit: PT Rineka Cipta: Jakarta.

Hamdani. 2011. Dasar - Dasar Kependidikan. Penerbit: CV Pustaka Setia: Bandung.

Iskandar, Harun. 2010. Tumbuhkan Minat Kembangkan Bakat. Penerbit: ST Book.

Moleong, J. Lexy. 2017. Metodologi Penelitian Kualitatif. Penerbit: PT Remaja Rosdakarya: Bandung.
Purwanto, M. Ngalim. 2007. Psikologi Pendidikan. Penerbit: PT Remaja Rosdakarya: Bandung.

Slameto. 2013 . Belajar dan Faktor-Faktor yang Mempengaruhinya. PT Rineka Cipta: Jakarta.

Slameto, 2016. Belajar dan Faktor -Faktor yang Mempengaruhinya. PT Rineka Cipta: Jakarta.

Sugiyono. 2016. Metode Penelitian Kuantitatif, Kualitatif dan $R \& D$. CV Alfabeta: Bandung.

Sugiyono. 2016. Memahami Penelitian Kualitatif. Penerbit:CV Alvabeta: Bandung

Analisis Faktor - Faktor yang Mempengaruhi Disiplin Belajar Siswa Kelas X, XI, dan XII Di SMA Bhakti Yasa Singaraja Tahun Pelajaran 2016/2017.E-journal Jurusan Pendidikan Ekonomi.Yuliyantika, Siska.2017. https://ejournal.undiksha.ac.id/.Vol:9.No. 1 Tahun 2017

Faktor yang mempengaruhi Pelanggaran Disiplin Siswa dan Implikasinya Terhadap Layanan Bimbingan dan Konseling. Jurnal IImiah Konseling.llahi Ridho,Syahniar,dkk.12 Mei 2013 Web. 05 Juni 2013.http://ejournal.unp.ac.id/index.php/ konselor.Vol:2. No.2 Juni 2013

Pelanggaran Tata Tertib yang dilakukan oleh Siswa di sekolah dan implikasinya terhadappelayanan bimbingan Konseling. Hendri,Yulfi dkk. 14 Mei 2014 Web. $\quad 30 \quad$ Juni 2014. http//ejournal.unp.ac.id/index.php/konsel or. Vol:3. No.2 Juni 2014.

Minat Belajar Sebagai Determinan Hasil Belajar Siswa.Nurhasanah, Siti dkk.01 Agustus 2016. http//ejournal.upi.edu/index.php/jpmanpe r. Vol:1. No.1 Agustus 2016. 